\title{
A conception of a mountain geopark in a SPA region; example of a projected Geopark ,Wisłok Valley - The Polish Texas”, in the Krosno region
}

Koncepcja górskiego geoparku na obszarze uzdrowiskowym na przykładzie projektowanego geoparku „Dolina Wisłoka - Polski Teksas”, ziemia krośnieńska

Radosław Wasiluk', Barbara Radwanek-Bąk ${ }^{2}$, Bogusław Bąk ${ }^{2}$, Robert Kopciowski², Tomasz Malata ${ }^{2}$, Alicja Kochman ${ }^{3}$, Andrzej Świąder ${ }^{3}$

${ }^{1}$ Polish Geological Institute - National Research Institute, ul. Rakowiecka 4, 00-975 Warszawa; e-mail: rwas@pgi.gov.pl

${ }^{2}$ Polish Geological Institute - National Research Institute, Carpathian Brand, ul. Skrzatów 1, Kraków;

e-mail:brad@pgi.gov.pl,bbak@pgi.gov.pl,kkop@pgi.gov.pl,tmal@pgi.gov.pl

${ }^{3}$ AGH University of Science and Technology,

al. A. Mickiewicza 30, 30-059 Kraków;

e-mail:alicja.kochman@agh.edu.pl; andrzej.swiader@agh.edu.pl
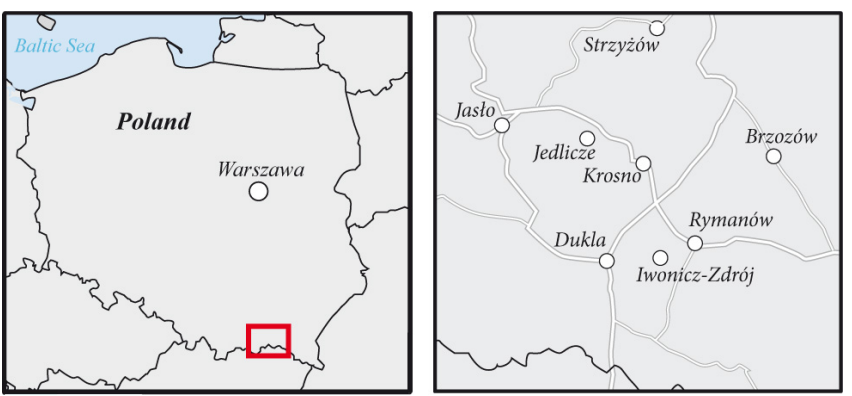

Abstract: The Polish Geological Institute - National Research Institute (PGI - NRI), in cooperation with AGH University of Science and Technology in Krakow carried out the project of new geopark in Poland - "Wistok Valley - The Polish Texas". It is located in the Polish Outer Carpathians (SE part of Poland). Oil fields, mineral water, nappe tectonics and other geological components of the Outer Carpathians constitute important elements of the geodiversity of this region. The area is located in the Krosno neighbourhood and encloses a zone of about $1000 \mathrm{~km}^{2}$. The Iwonicz-Zdrój - Rymanów-Zdrój SPA region is also included in the research area. It covers 20 municipalities of the Podkarpackie province. For the project of the Geopark, a geotouristic map, geosites, geological-educational paths, website, advertising brochures, geological-educational tables and a movie were made, which promote geotourism. The final product will be targeted at regional and local public administration bodies, national and landscape Parks, the State Forests National Forest Holding and local tourist organizations.

Key words: geopark, geotourism, Outer Carpathians, crude oil
Treść: Państwowy Instytut Geologiczny - Państwowy Instytut Badawczy we wspótpracy z Akademia Górniczo-Hutnicza w Krakowie zrealizowat projekt nowego geoparku w Polsce „Dolina Wistoka - Polski Teksas". Ma się on znajdować w Karpatach zewnętrznych. Złoża ropy naftowej, wody mineralne, tektonika plaszczowinowa i inne geologiczne cechy Karpat zewnętrznych składaja się na georóżnorodność tego rejonu. Obszar tego opracowania obejmowat ponad $1000 \mathrm{~km}^{2} w$ rejonie Krosna właczajac $w$ to również teren uzdrowisk Iwonicza-Zdroju i Rymanowa Zdroju. Projekt ten objąt swym zasięgiem 20 gmin województwa podkarpackiego. W ramach projektu wykonano mape geologiczno-turystyczna, udokumentowano ponad 150 geostanowisk $i$ zaprojektowano dziewięć ścieżek geologiczno-edukacyjnych. Przygotowano też dwa foldery, 12 tablic geologiczno-edukacyjnych, zaprojektowano strone internetowa o projekcie oraz nakręcono film promocyjny. Produkt końcowy skierowany jest do wykorzystania w promocji regionu do samorzadów lokalnych, parków krajobrazowych i narodowych, lasów państwowych oraz lokalnych organizacji turystycznych.

Slowa kluczowe: geopark, geoturystyka, Karpaty zewnętrzne, ropa naftowa

\section{Introduction}

Today, tourists are more demanding Therefore qualified tourism like, for example, geotourism is developing quickly (Jezierski, 2011; Migoń, 2012). Geoparks are examples of complex and complete geotourist products (Alexandrowicz Z., Alexandrowicz S., 2004). In the Polish Carpathians, many locations were proposed for projected geoparks 
(Golonka, Krobicki, 2007; Miśkiewicz, Golonka, 2007; Krobicki, Golonka, 2008; Miśkiewicz et al., 2011; Golonka et al., 2013; Wasiluk, 2013). One of the most interesting regions for geo-education and geotourism in the Polish Outer Carpathians is area of Bóbrka village (Ślączka, Kamiński, 1998). In this village, there is evidence, that during the second half of the 19th Century, a branch of the oil industry was born in Poland. In the late XIX century, during an oil boom in the neighborhood, in Rymanów-Zdrój and Iwonicz-Zdrój, a new source of mineral-water was discovered and developed into a SPA. Particularly in SPA regions, tourists are looking for new attractions (Buczek-Kowalik, Jurczak,
2014; Buczek-Kowalik, Łuka, 2015). Near Krosno, many interesting quarries, outcrops and relices of ancient mining exist (Słomka et al., 2006; Bubniak, Solecki (eds), 2013; Wójcik et al., 2014). In this area, PGI-NRI realized the project of a new Geopark "Wisłok Valley - The Polish Texas" (Fig. 1). This project was produced on the order of the Minister of the Environment and financed by the National Fund for Environmental Protection and Water Management. The aim of the paper is to present the results of an inventory of geosites in the Krosno region. Geosites were selected, and their quantitative assessment and geotourism potential were analysed.

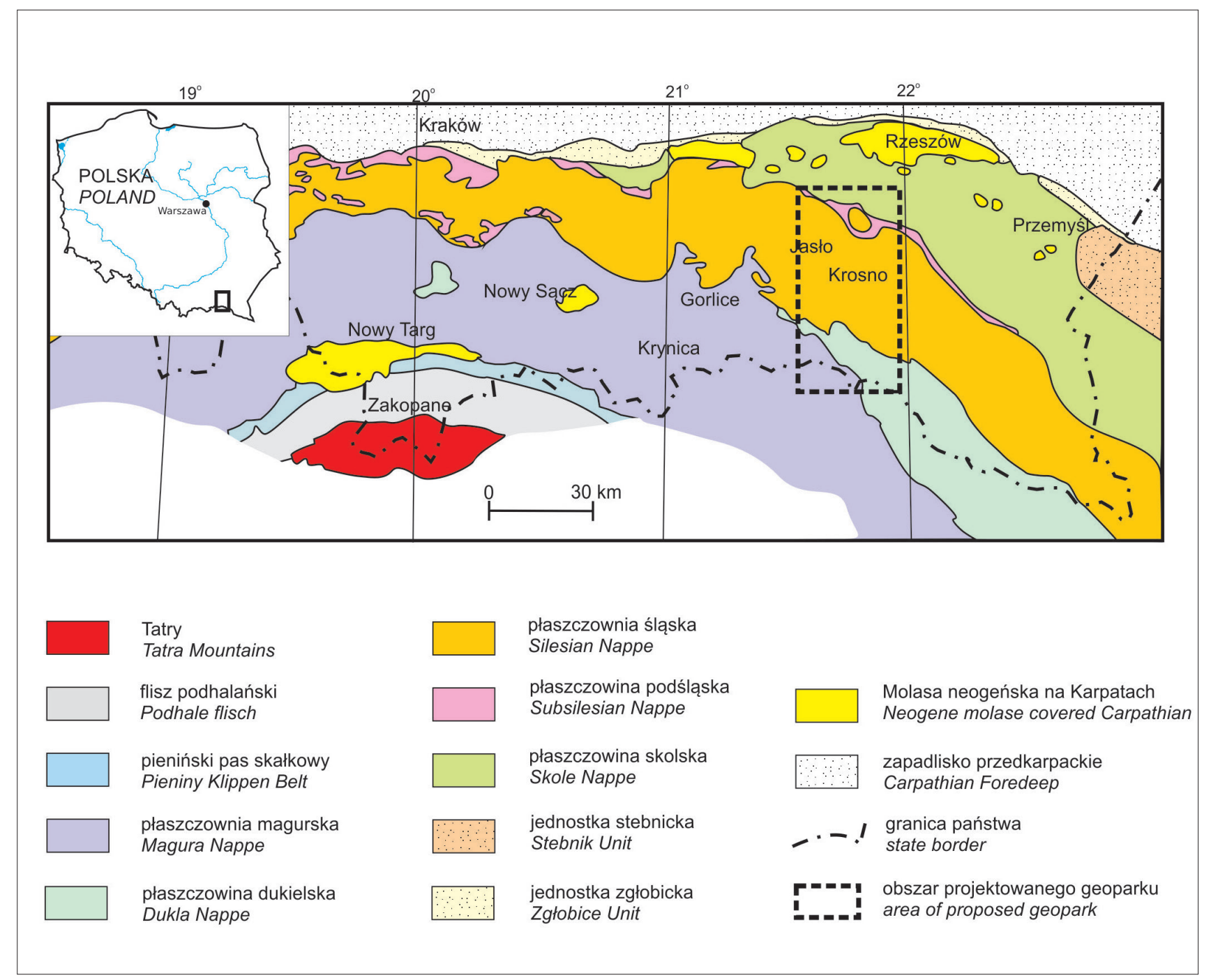

Fig. 1. Schematic geological map of the Polish Carpathian (Oszczypko et al., 2006, modified) • Schematyczna mapa geologiczna Karpat polskich (Oszczypko et al., 2006, zmienione)

\section{Localization and geological background}

The area is located in the Beskid Niski Range, in the Jasło-Sanok Basin and Strzyżów, Dynów, Jasło and Bukowskie
Foothills, between Strzyżów and Barwinek. It encloses an area of about $1000 \mathrm{~km}^{2}$ and includes the Iwonicz-Zdrój Rymanów-Zdrój SPA region. It covers 20 municipalities in five counties of the Podkarpackie province: Krosno, Jasło, Brzozów, Strzyżów, Sanok (Fig. 2). 
The area of the proposed Geopark "Wisłok Valley - Polish Texas" is one of classical terrain of geological research in the Polish Outer Carpathians. In this area, there are all main tectonical units in the Outer Carpathian like: Magura,
Dukla, Silesian, Subsilesian and Skole nappes (Figs 1, 2). This is an area where typical Carpathian rocks, stratotype sections and sediments of Pleistocene glacial maximum occur.

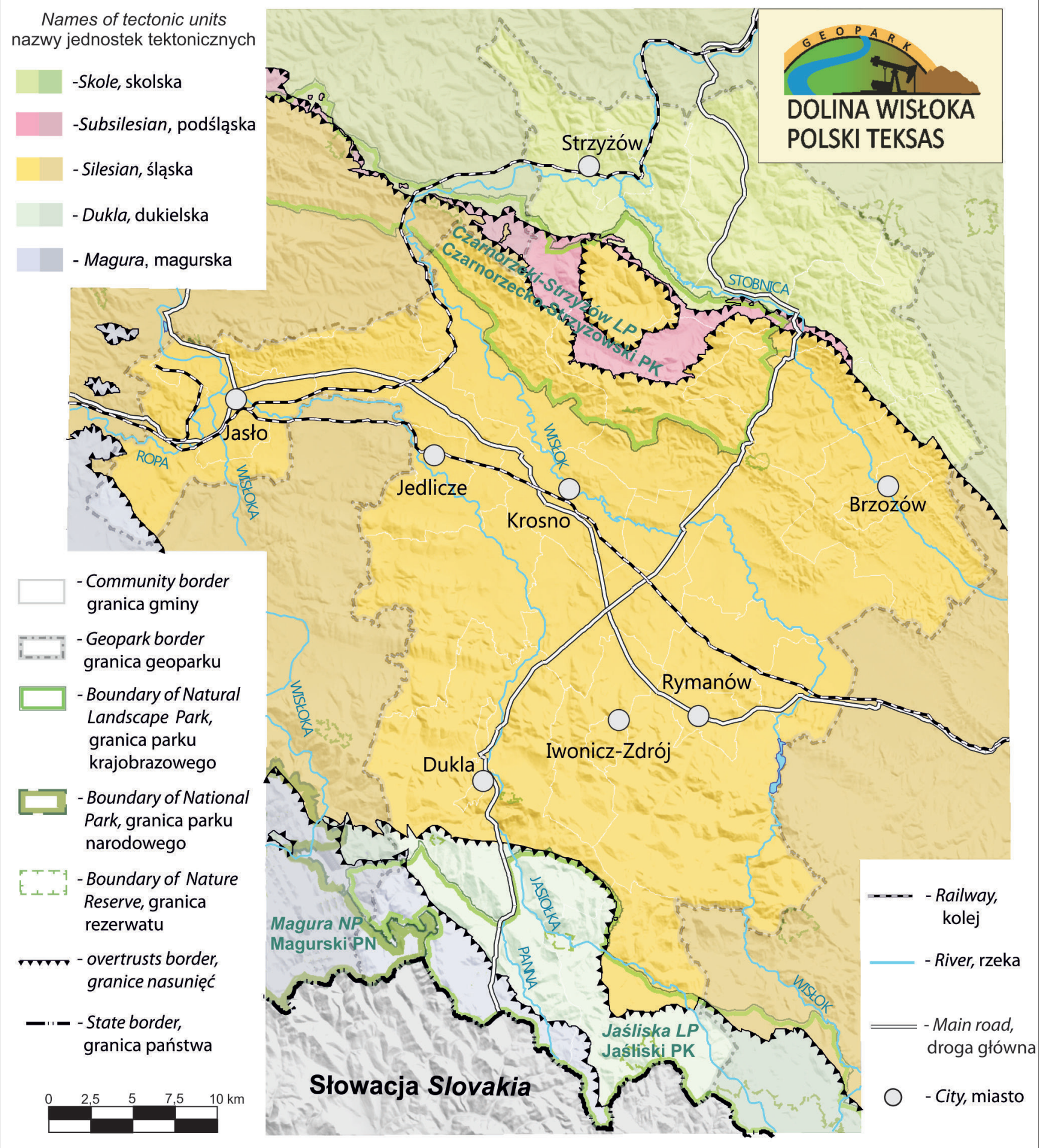

Fig. 2. Location of research. The boundaries of the municipalities covered by the project of the geopark in the background of a schematic geological map • Lokalizacja badań. Granice gmin objętych projektem geoparku na schematycznej mapie geologicznej 


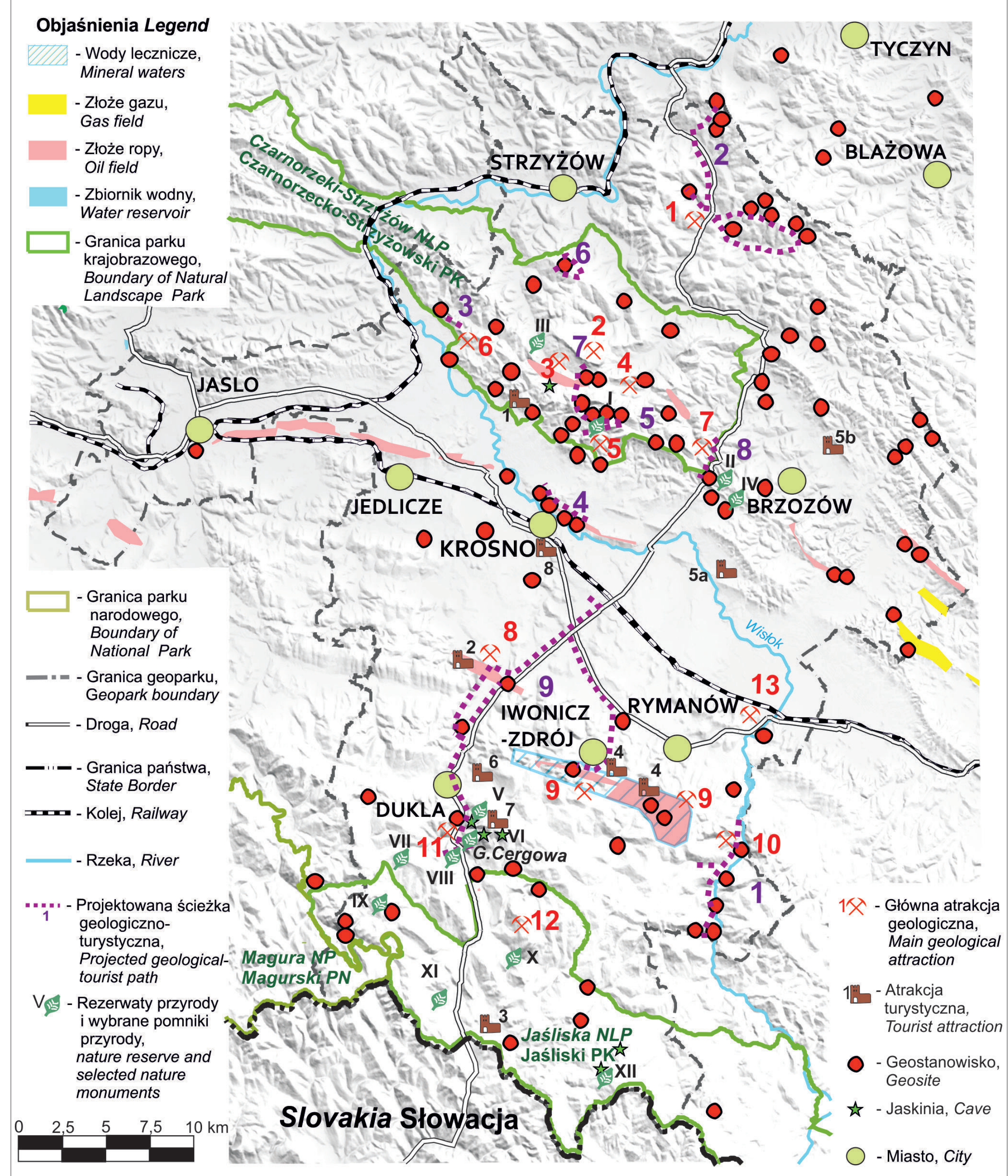

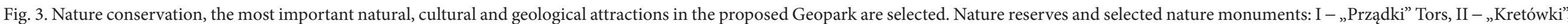

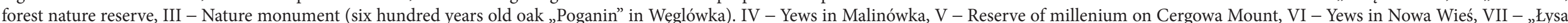

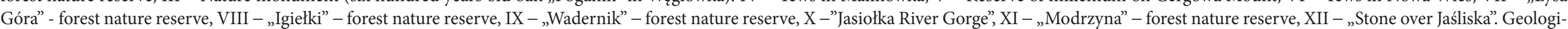

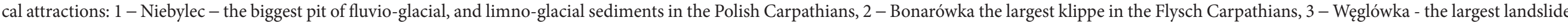

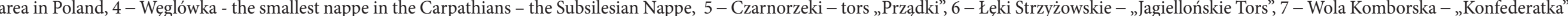

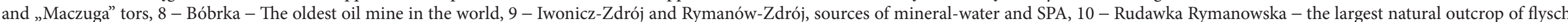

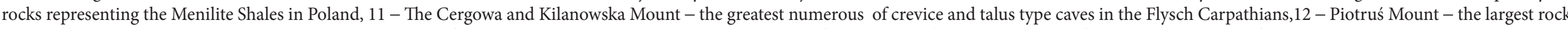

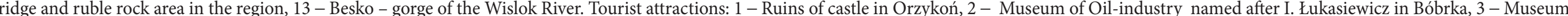

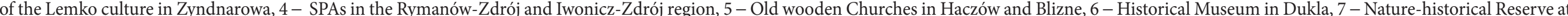

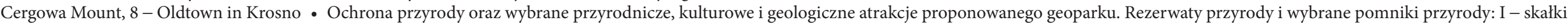

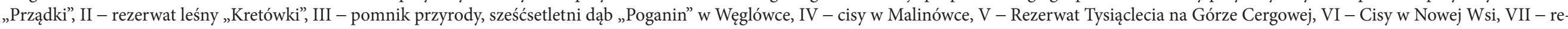

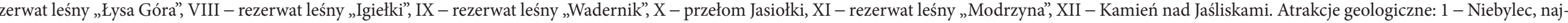

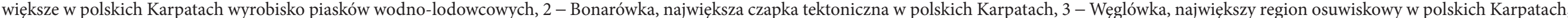

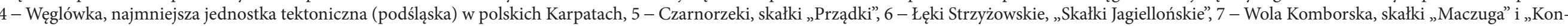

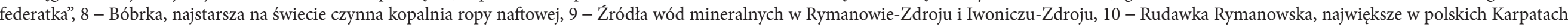

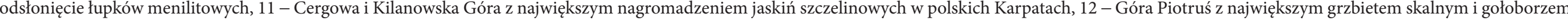

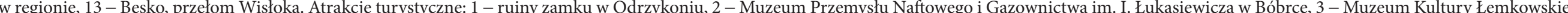

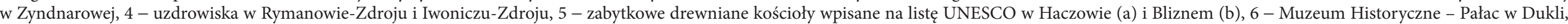
7 - rezerwat historyczno-przyrodniczy na Górze Cergowej, 8 - stare miasto w Krośnie 


\section{Geological attractions}

The proposed Geopark contains many interesting, different geological attractions in the Polish Carpathians. The most important geosites are listed below and shown on (Fig. $3-$ interleaf):

- In Niebylec village, there is the biggest pit of fluvio-glacial, and limno-glacial sediments in the Polish Carpathians (Wójcik, 1999).

- Bonarówka village is located on the largest klippe in the Polish Outer Carpathians.

- It is surrounded, in Węglówka and Brzeżanka, by the largest landslide area in Poland, where landslides are even 5 $\mathrm{km}$ wide and over $1 \mathrm{~km}$ long.

- Węglówka is the site of typical development and greatest extent of rocks of the smallest nappe in the Carpathians the Subsilesian Nappe.

- A group of tors „Prządki” - reservoir rocks for oil and gas (Ciężkowice sandstones) Czarnorzeki-Odrzykoń (Świdziński, 1933; Alexandrowicz, 2007).

- A group of „Jagiellońskie Tors” - formed by Ciężkowice sandstones, near Łęki Strzyżowskie.

- „Konfederatka” and „Maczuga” tors formed by Istebna sandstones, near Wola Komborska.

- The oldest crude oil mine in the world in Bóbrka (Radwański, 2009).

- Sources of mineral-water and ancient oil-fields in the SPA region of Iwonicz-Zdrój and Rymanów-Zdrój.

- Rudawka Rymanowska includes the largest natural outcrop of flysch rocks representing the Menilite Shales in Poland. Organic matter from Menilite Shales gave origin to numerous oil fields in the Carpathians. This outcrop, comprising a thrust, anticline, syncline and faults, is also the most picturesque one in the Carpathians.

- The Cergowa and Kilanowska Mount, near Dukla, include one of the greatest assemblages of crevice and talus type caves in the Flysch Carpathians (Jankowski et al. (eds), 2012).

- On The Piotruś Mount largest rock ridge and rubble rock area are found in this region.

- Besko - large gorge of the Wislok River.

One of the types of geosites includes sources of mineral water. Their intakes are located in the area of Iwonicz Zdrój and Rymanów. Mineral waters may be of various origin. They develop from rainwater that percolates through rocks and becomes enriched in the washed out mineral compounds or from connate relic sea water flowing out from the depths of the Earth. Areas of Iwonicz Zdrój and Rymanów include chloride and sodium carbonated waters; occasionally ferruginous and with iodine and bromine ions (Rajchel et al. (eds), 2011). The salty, strongly mineralized chloride waters are the connate waters of the ancient Tethys Ocean and natural gas exhalations in its spring. They are found in Rudawka Rymanowska, Iwonicz-Zdrój and Rymanów-Zdrój (Fig. 4).

Other interesting type of gesites are crude oils. The oldest oil mine in the world is located in Bóbrka village, near Krosno. Presently, there is the Ignacy Łukasiewicz Museum of Oil and Gas Industry. Ignacy Łukasiewicz was a pharmacist. He is the father of the global crude oil industry. He established the first oil mine and distillery in the world. Numerous oil mines operating since the $19^{\text {th }}$ century may be observed in the Geopark, e.g. in Iwonicz Zdrój, Rymanów, Wietrzno, Rogi, Bóbrka, Potok, Krosno, Krościenko, Grabownica Starzeńska, Turze Pole, and Węglówka (Fig. 3).

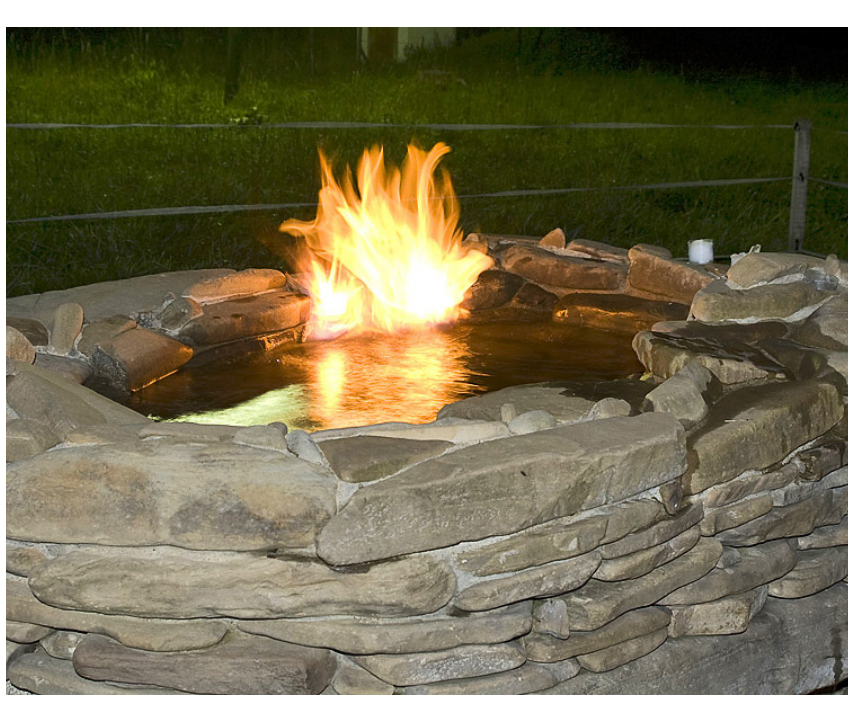

Fig. 4. Natural gas exhalations in the "Bulgotka" ("Bubbler") spring in Rudawka Rymanowska, photo R. Wasiluk - Naturalny wypływ gazu ziemnego, źródło „Bulgotka” w Rudawce Rymanowskiej, fot. R. Wasiluk

Oil is originated from rocks rich in organic matter, particularly dark shales (menilite beds). The rocks which generate hydrocarbons are referred to as source rocks. The organic matter is transformed into oil in rocks that are heated up to over $60^{\circ} \mathrm{C}$. Such a temperature is over $2 \mathrm{~km}$ below ground surface. The oil is generated in conditions of up to $4 \mathrm{~km}$ and $120^{\circ} \mathrm{C}$, while gas is formed at greater depths and temperatures. The organic matter in shales, giving origin to oil and gas, derives mainly from planktonic, microscopic and unicellular algae (chrysophytes) and protozoans (foraminifers, radiolarians and diatoms). From the source rock, hydrocarbons move (migrate) upwards and accumulate in porous sandstones, forming a field. The field must be isolated by overlying impermeable rocks called sealing rocks, mainly clayey shales. Porous sandstones accumulating oil and gas are referred to as reservoir rocks. Reservoir and sealing rocks form the so-called hydrocarbon trap.

In the Flysch Carpathians, traps were developed in upward-convex folds - anticlines (Fig. 5). The area of the park includes numerous anticlines with hydrocarbon deposits, e.g. anticlines of Iwonicz, Bóbrka, Potok, Turze Pole, and Grabownica. In the Turze Pole field, recovered light oil can be found. Its quality is so high, that it can be used as fuel in some diesel engines without earlier purification in a refinery. The black, brown and beige Menilite Shales are the main source rock for hydrocarbons. The rocks are of Oligocene age, i.e. 34-23 mln years old. 

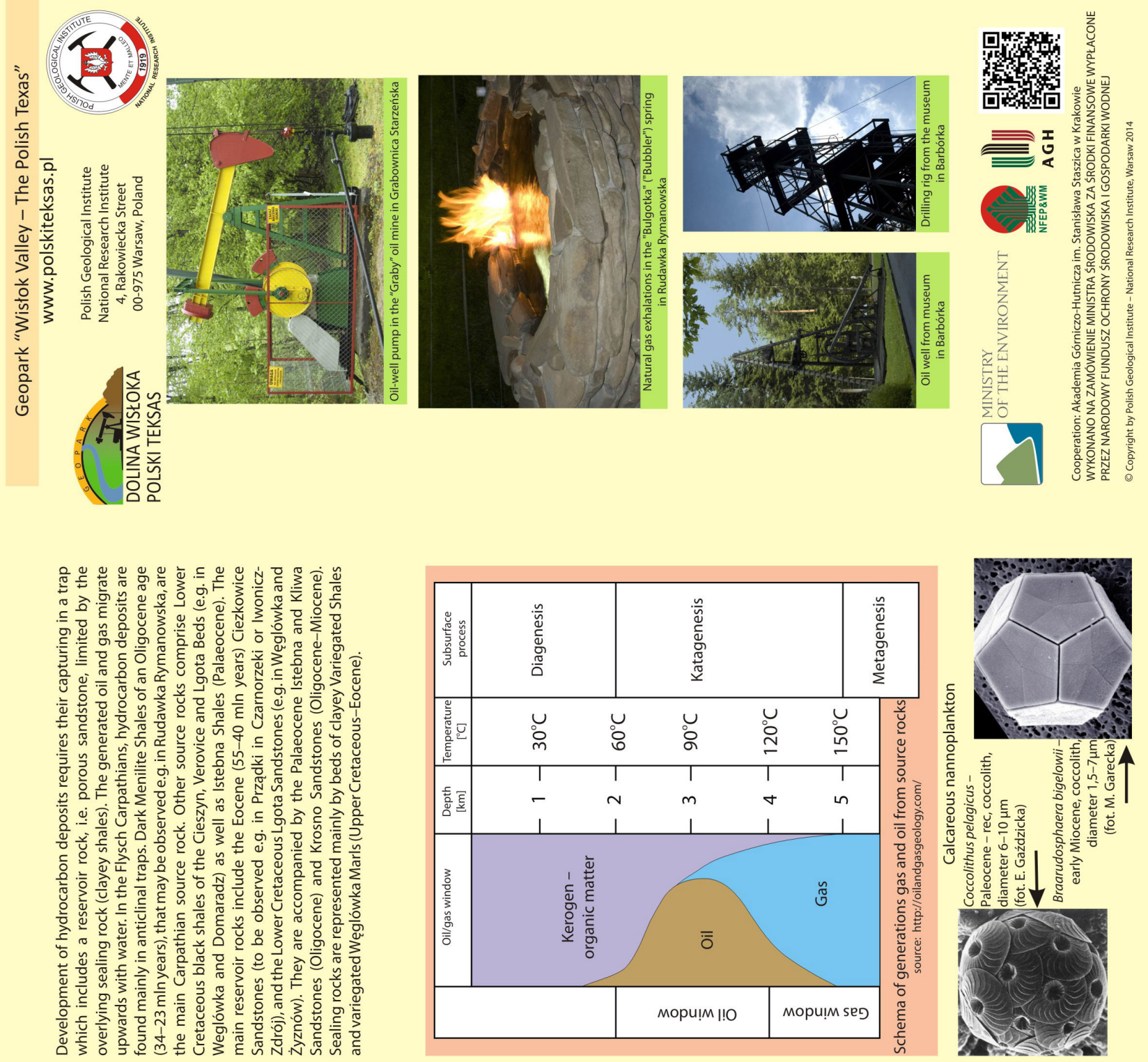

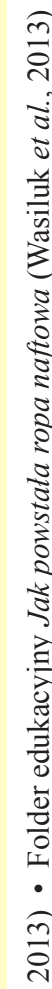

Many interesting tors have been discovered on the researched terrain. The Carpathian rocks were folded and crusted about $17 \mathrm{mln}$ years ago. This is because, the Outer Carpathians formation rocks were eroded. Wind, frost and rain are forming mountains, and special rock-forms - tors (Fig. 6). Wola Komborska includes one of the largest groups of tors, formed of Istebna Sandstones, of Palaeocene age (65-56 mln years) in the Outer Carpathians. The "Maczuga" and "Konfederatka" tors are the most known. One of the largest and most picturesque groups of tors, named "Prządki" tors, formed of Ciężkowice Sandstones of Eocene age (56-34 mln years) are situated in Czarnorzeki. Odrzykon is the location of ruins of the "Kamieniec" castle, built on a rock formed of Ciężkowice Sandstones and with numerous tors of the „Krowia Turnia” group in the surroundings. The history of the castle's residents was described by Aleksander Fredro in „Zemsta”. The series of tors extends on a crest, from Wola Komborska in the East, through Czarnorzeki, to Frysztak in the West (Fig. 3).

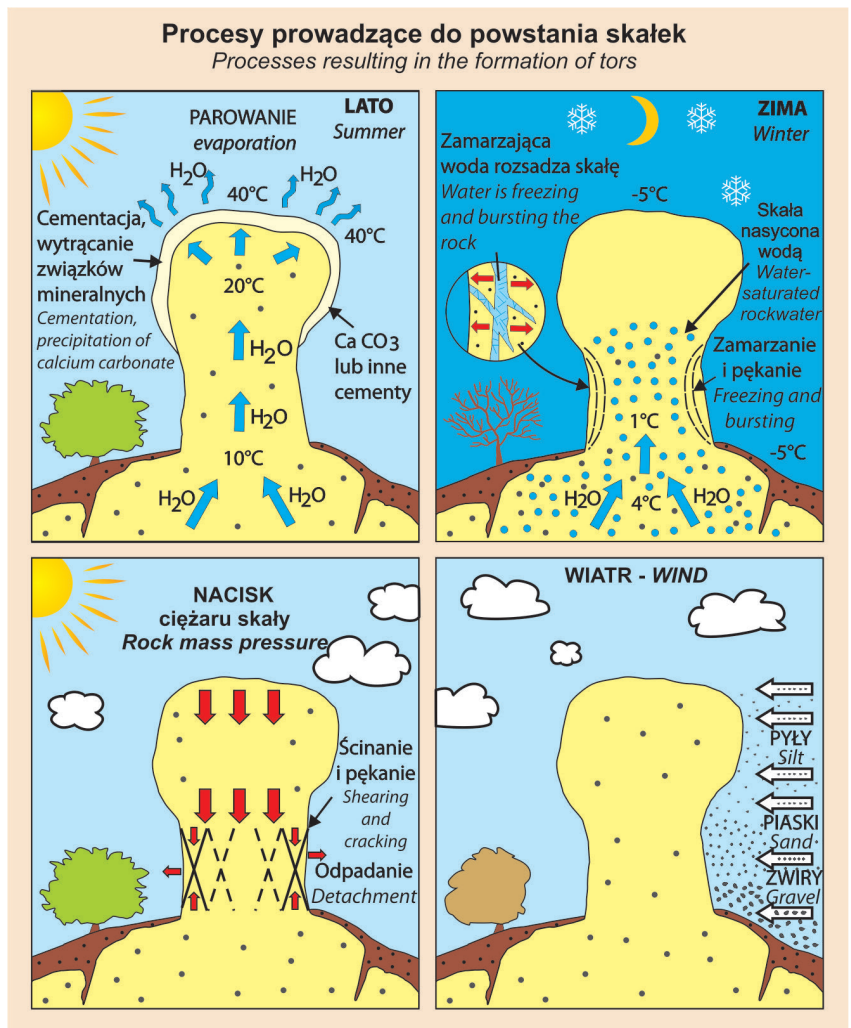

Fig. 6. Part of the educational table "Prządki" tors (Wasiluk et al., 2013) • Fragment tablicy edukacyjnej skałki „Prządki” (Wasiluk et al., 2013)

For many tourists, caves are the most interesting geosites. The Cergowa and Kilanowska Mountains include one of the greatest assemblage of fissure caves in the Outer Carpathians (Fig. 3). Those caves, in contrast to karstic caves, were formed in rock fissuring during landslides (Fig. 7). On the Kilanowska Mountain, 60 landslide caves were already documented, and new ones are still being discovered (Jankowski et al., 2012). The Słowiańska-Drwali Cave is the largest one in Beskid Niski. With its over $500 \mathrm{~m}$ long passages, it is also one of the longest cave in the Outer Carpathians. These caves are typified by an interesting feature - dynamics. Both gradual and rapid landslide movements result in the compression or formation of caves and changes in their passages. In some of them, ice remains for most of the year. Entering such caves requires specialized cave equipment.

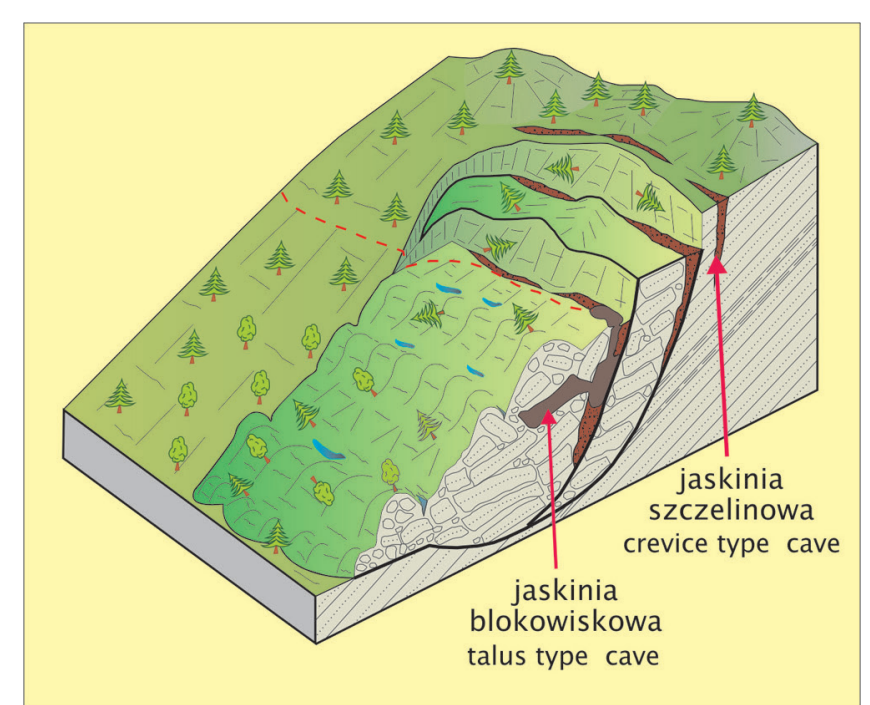

Fig. 7. Types of caves associated with landslides (Kucharska et al., 2003; modified) - part of the educational table Cergowa and Kielanowska Mount - caves (Wasiluk et al., 2013) • Typy jaskiń związane z osuwiskami (Kucharska et al., 2013; zmienione) - fragment tablicy edukacyjnej Jaskinie Cergowej i Kielanowskiej Góry (Wasiluk et al., 2013)

\section{Results of the project}

For the project of the Geopark a geotourist map, 155 geosites and 9 geological-educational paths (Fig. 3) were created (Wasiluk et al., 2013, 2014 a, b). Paths connected the most interested geosites:

- „Along the Wisłok river” - between Rudawka Rymanowska and Wernejówka,

- Gwoździanka-Niebylec-Gozdnica-Konieczkowa,

- „Jagiellońskie Tors”,

- Krosno - Wisłok river - fold of Potok,

- Węglówka-Czarnorzeki along Czarny Potok,

- Landslide in Brzeżanka,

- Landslide in Węglówka,

- Tors „Konfederatka” and „Maczuga” in Wola Komborska,

- Around Iwonicz-Zdrój.

The results also contain: the Geopark website (www.polskiteksas.pl), two different advertising brochures, twelve geological-educated tables and a movie that promotes geoturism (Fig. 8). The biggest work and the main scientific problem was the preparation of a geological-tourist map in the scale of 1:50 000 (Fig. 9). It was made on the basis of 12 sheets of Detailed Geological Maps of Poland. The oldest map was made in the early 1980's, and the youngest is new. The geological-touristic map, as all maps in PGI-NRI (Rychel et al., 2012, 2013), was created with a GIS application called ArcMap. 


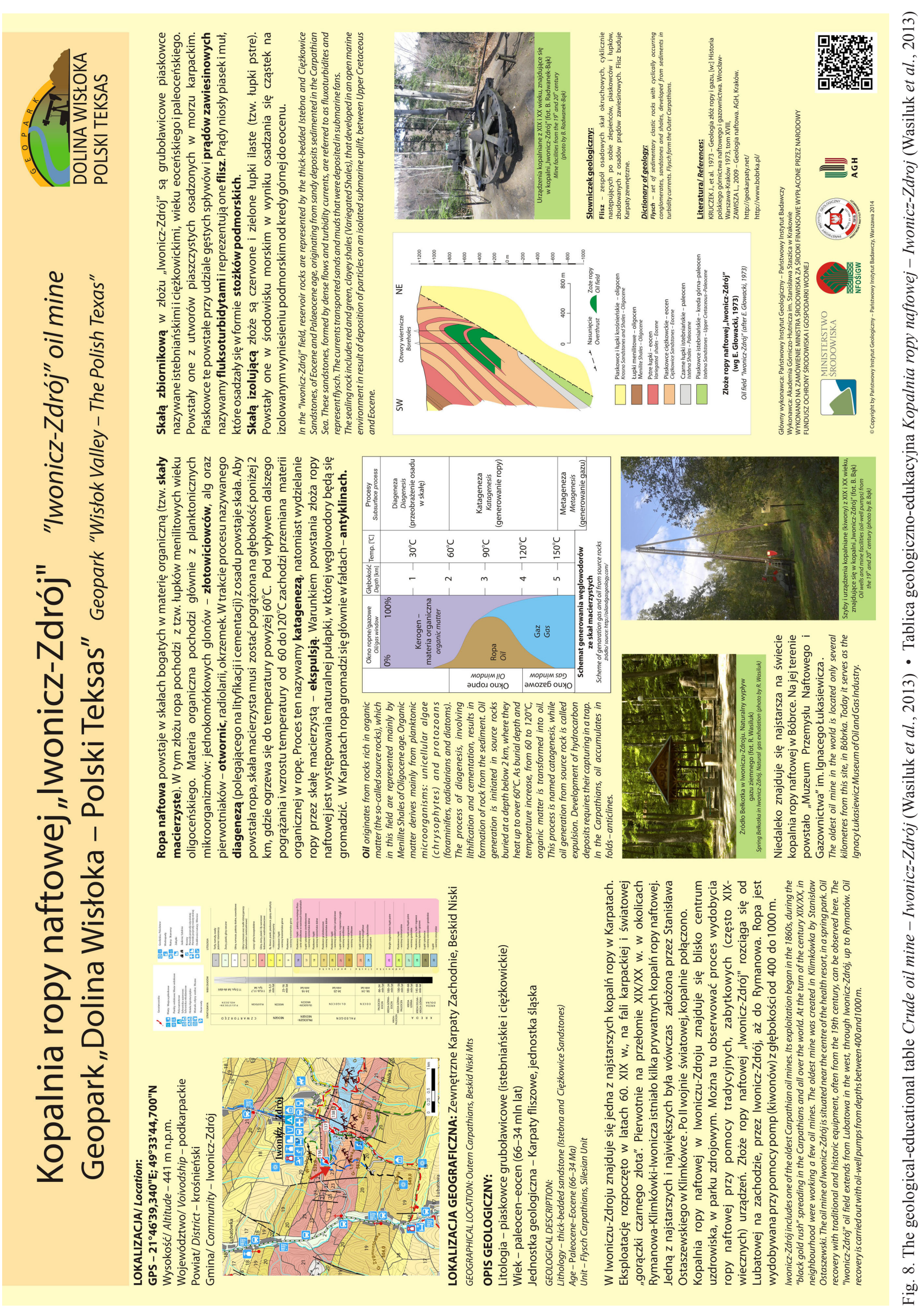




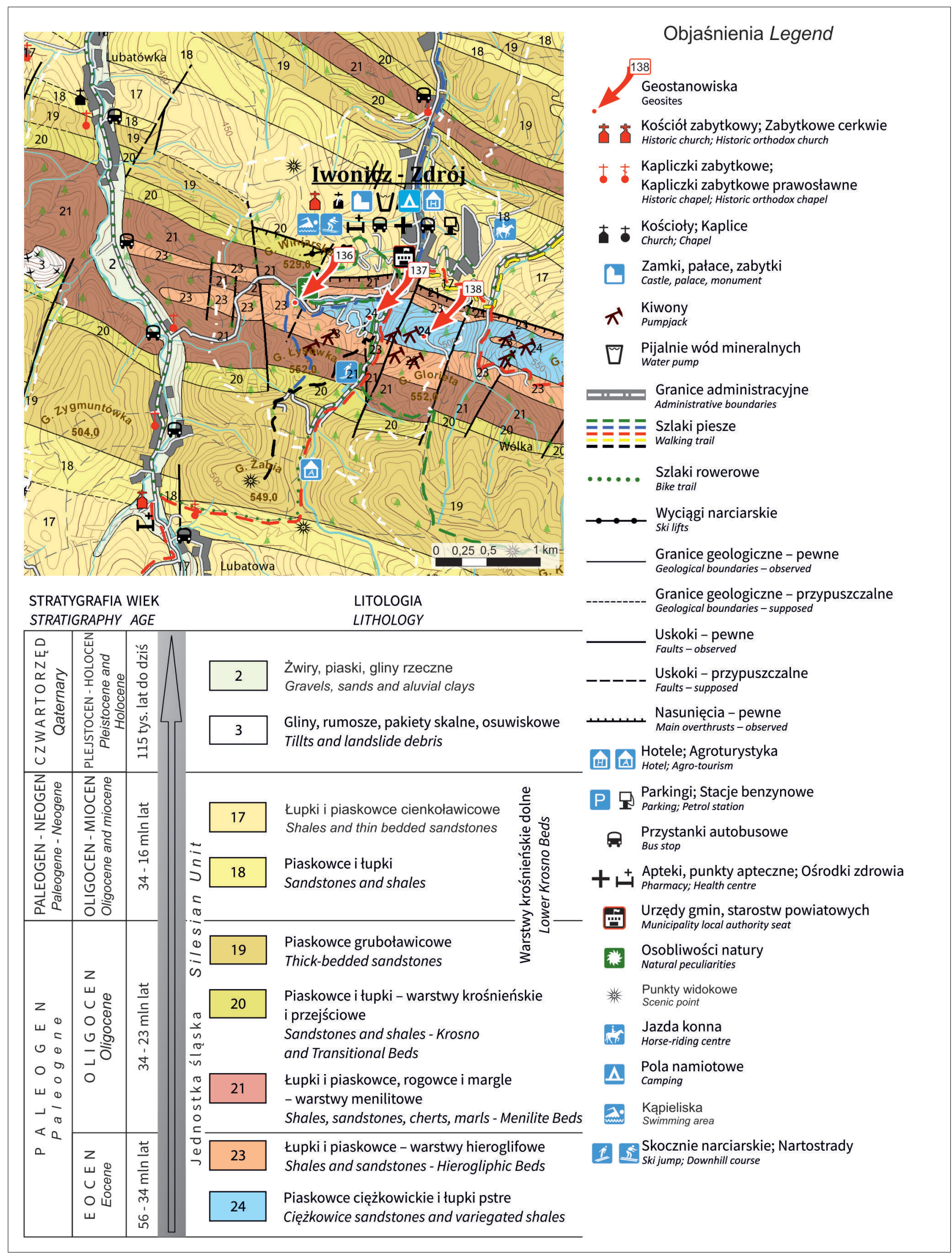

Fig. 9. Part of geological-tourist map, area of Iwonicz-Zdrój with interesting geosites (136-138) (Wasiluk et al., 2013): 136 - Crudeoil Mine Iwonicz Zdrój, 137 - Ciężkowice sandstone - outcrop,138 - Cherts of Menilite Beds - outcrop • Mapa geologiczno-turystyczna okolic Iwonicza-Zdroju z interesującymi geostanowiskami (136-138) (Wasiluk et al., 2013): 136 - kopalnia ropy naftowej Iwonicz-Zdrój, 137 odsłonięcie piaskowców ciężkowickich, 138 - odsłonięcie rogowców z warstw menilitowych 


\section{Summary}

Results of our work proved that area of the proposed geopark has a big potential for geotourism, education and science. This research is a good background for the development of the touristic potential for local self-goverment
(Zawilińska et al., 2015). In PGI-NRI, many geotouristic projects for Earth sciences were made. The Institute has vast experience in geotourism and a skilled science staff. PGINRI invites all concerned governments, universities and another scientists or regional centers to cooperate and work together.

\section{Streszczenie}

\section{Koncepcja górskiego geoparku na obszarze uzdrowiskowym} na przykładzie projektowanego geoparku „Dolina Wisłoka - Polski Teksas”, ziemia krośnieńska

\section{Radosław Wasiluk, Barbara Radwanek-Bąk, Bogusław Bąk, Robert Kopciowski, Tomasz Malata, Alicja Kochman, Andrzej Świąder}

Współczesny turysta jest coraz bardziej wymagający, poszukuje on zróżnicowanych i innowacyjnych atrakcji. Jedną z rozwijających się gałęzi specjalistycznej turystyki edukacyjnej jest geoturystyka (Jezierski, 2011; Migoń, 2012). Geopark to najbardziej kompletny, kompleksowy produkt geoturystyczny, który można zaproponować odbiorcom (Alexandrowicz, Alexandrowicz, 2004). Jednym z bardziej interesujących geoturystycznie miejsc w Polsce są tereny górskie, a w polskich Karpatach fliszowych są to okolice Bóbrki na ziemi krośnieńskiej (Ślączka, Kamiński, 1998; Bubniak, Solecki, 2013). Ze względu na dużą georóżnorodność oraz mnogość innych atrakcji turystycznych w PIGPIB powstał pomysł na zaprojektowanie geoparku na ziemi krośnieńskiej.

W PIG-PIB we współpracy z AGH w Krakowie, w latach 2011-2014 na zamówienie Ministerstwa Środowiska powstał projekt geoparku „Dolina Wisłoka - Polski Teksas”.

Obszar projektowanego geoparku rozciąga się od granicy państwa w okolicach Barwinka do okolic Strzyżowa i wynosi ponad $1000 \mathrm{~km}^{2}$. Geograficznie teren ten leży w obrębie Beskidu Niskiego, Dołów Jasielsko-Sanockich i pogórzy Dynowskiego, Jasielskiego, Strzyżowskiego i Bukowskiego. Geologicznie teren badań należy do zewnętrznych Karpat fliszowych. Na tym terenie znajdują się wszystkie główne tektoniczne jednostki fliszowe: magurska, dukielska, śląska, podśląska i skolska (Fig. 1,2).

Przewodnim tematem na terenie projektowanego geoparku jest ropa naftowa. Najstarsza na świecie kopalnia ropy znajduje się w Bóbrce koło Krosna (Fig. 3). Obecnie jest to Muzeum Przemysłu Naftowego i Gazowniczego im. Ignacego Łukasiewicza. Ignacy Łukasiewicz, farmaceuta z wykształcenia, był ojcem światowego przemysłu naftowego, założył pierwszą kopalnię i destylarnię ropy naftowej na świecie. Na terenie geoparku występuje wiele kopalń ropy działających od XIX w., np. w Iwoniczu-Zdroju, Rymanowie,
Wietrznie, Rogach, Bóbrce, Potoku, Krośnie, Krościenku, Grabownicy Starzeńskiej, Turzym Polu, Węglówce (Fig. 3). Złoża ropy naftowej powstały ze skał bogatych w materię organiczną (skały macierzyste), głównie z ciemnych łupków - menilitowych, które możemy obejrzeć m.in. w największym ich odsłonięciu w Rudawce Rymanowskiej (Fig. 3). Porowate piaskowce, w których gromadzi się ropa i gaz nazywamy skałami zbiornikowymi. Skały zbiornikowe i izolujące tworzą tzw. pułapkę dla węglowodorów. W Karpatach fliszowych pułapkami są fałdy - antykliny, wypukłe ku górze (Fig. 5).

Znajduje się tu jedno z najstarszych uzdrowisk w Polsce, Iwonicz-Zdrój. Informacje o występowaniu w tym rejonie wód leczniczych pochodzą już z XV wieku. W drugiej połowie XIX w. i na początku XX w., podczas gorączki czarnego złota, uzdrowiska Rymanów-Zdrój i Iwonicz-Zdrój przeżywały największy rozkwit. Wody mineralne podczas wędrówki z głębi ziemi w skałach wzbogacają się w różne związki mineralne. Występują tu wody lecznicze o zróżnicowanym składzie: chlorkowe, sodowe, żelazowe, bromowe, jodowe i inne (Rajchel et al., 2011). Występują tu też solanki będące reliktowymi wodami pradawnego oceanu Tetydy. Źródła „Bełkotka” w Iwoniczu-Zdroju i „Bulgotka” w Rudawce Rymanowskiej (Fig. 4) są przykładem naturalnych ekshalacji gazu ziemnego.

Karpaty zewnętrzne wypiętrzyły się około $17 \mathrm{mln}$ lat temu. Od tego momentu skały karpackie były niszczone. Wiatr, mróz i deszcz rzeźbiły góry i formowały specyficzne formy ostańcowe - skałki (Fig. 6). W Woli Komborskiej znajduje się jedna $\mathrm{z}$ największych w Karpatach fliszowych grup skałek utworzonych $\mathrm{z}$ piaskowców istebniańskich wieku paleoceńskiego (65-56 mln lat) (Fig. 3). Najbardziej znane to „Maczuga” i „Konfederatka”. W Czarnorzekach znajduje się jedna z największych i najbardziej malowniczych grup skałek - „Prządki” - utworzonych z piaskowców ciężkowickich wieku eoceńskiego (56-34 mln lat). W okolicach Łęków Strzyżowskich znajduje się grupa „Skałek Jagiellońskich". Na Górze Piotruś koło Jaślisk znajduje się najdłuższa w regionie grzęda skalna i gołoborze.

W okolicach Dukli na Cergowej i Kilanowskiej Górze znajduje się największe nagromadzenie jaskiń szczelinowych w Karpatach fliszowych. Są to w odróżnieniu od jaskiń krasowych formy powstałe jako szczeliny w trakcie osuwania się skał (Fig. 7). Największą jest Jaskinia Słowiańska-Drwali o długości korytarzy ponad 500 metrów. Jest ona jedną z najdłuższych w Karpatach fliszowych.

Innymi atrakcjami na skalę krajową i regionalną są największe w Karpatach polskich odsłonięcia piasków wodno-lodowcowych i iłów jeziorno-lodowcowych w Niebylcu, wychodnie skał (stratotyp) najmniejszej karpackiej jednostki - podśląskiej w Węglówce. Płaskowyż Bonarówki 
jest największą w polskich Karpatach czapką tektoniczną. W okolicach Węglówki występuje największy w Polsce rejon osuwiskowy. W Besku znajduje się jeden z najbardziej malowniczych przełomów rzecznych, przełom Wisłoka.

Na potrzeby projektu sporządzono mapę geologiczno-turystyczną, opracowano 155 geostanowisk oraz zaprojektowano dziewięć ścieżek geoturystycznych (Fig. 3) (Wasiluk et al., 2014a, b). Na opracowanie składa się również strona internetowa o projekcie (www.polskitexas.pl), dwa foldery edukacyjno-promocyjne, 12 tablic geoturystyczno-edukacyjnych
(Fig. 8) oraz film promocyjny. Mapa geologiczno-turystyczna (Fig. 9) powstała na podstawie dwunastu arkuszy Szczegółowej mapy geologicznej Polski w skali 1:50 000. Mapa została wykonana w technologii GIS w aplikacji ArcMap.

Wykonany projekt potwierdził duży potencjał geoturystyczny badanego obszaru, zgromadzono olbrzymią dokumentację potrzebną do utworzenia geoparku. PIG-PIB potwierdził swą dużą kompetencję i ponaddwudziestoletnie doświadczenia w geoturystyce.

\section{References (Literatura)}

Alexandrowicz Z., 2007. 50 czy 75 lat ochrony skałek „Prządki” koło Krosna?. Chrońmy Przyrode Ojczysta - forum

Alexandrowicz Z., Alexandrowicz S., 2004. Geoparks - the most valuable landscape parks in southern Poland. Polish Geological Institute Special Papers, 13: 49-56.

Buczek-Kowalik M., Jurczak D., 2014. Turystyka zdrowotna w uzdrowiskach Beskidu Niskiego na przykładzie Iwonicza-Zdroju i Rymanowa-Zdroju, In: Bubniak I.M., Solecki A.T. (eds), Geo-Carpathians-Potential of the Cognitive Tourism. Ruthenus, Krosno, 131-144.

Buczek-Kowalik M., Łuka P., 2015. Innowacje turystyczne w wybranych gminach uzdrowiskowych województwa podkarpackiego. Rozprawy $\mathrm{Na}$ ukowe Akademii Wychowania Fizycznego we Wroctawiu, 49: 135-146.

Bubniak I.M., Solecki A.T. (eds), 2013. Przewodnik geoturystyczny po szlaku GEO-KARPATY, Krosno-Borystaw-Jaremcze. Wydawnictwo Ruthenus, Krosno.

Golonka, J., Krobicki, M., 2007. Dunajec River rafting as one of the most important geotouristic object of the future trans-bordering PIENINY Geopark. Geotourism, 3 (10): 29-44.

Golonka J., Krobicki M., Miśkiewicz K., Słomka T., Waśkowska A., Doktor M., 2013. Geopark „Beskid Śląsko-Morawsko-Żywiecki”-najstarsze utwory Karpat fliszowych. Przeglad Geologiczny, 61: 277-285.

Jankowski L., Margielewski W., Urban J. (eds), 2012. Strukturalne i litofacjalne uwarunkowania rozwoju rzeźby polskich Karpat zewnętrznych. III Warsztaty Geomorfologii Strukturalnej. Beskid Niski-Beskid Sąecki-Babia Góra, Przewodnik do wycieczek terenowych, 25-28 wrzesień 2012. Instytut Ochrony Przyrody PAN, Kraków, 34-80.

Jezierski H.J., 2011. Geoturystyka wypaliła. Przegląd Geologiczny, 59: 254-257.

Krobicki M., Golonka J., 2008. Geotouristical values of the Pieniny Klippen Belt and Tatra Mountains regions (Poland). Przegląd Geologiczny, 56: 670-679.

Kucharska M., Krawczyk M., Kamiński M., Chowaniec J., 2013. Mapa geologiczno-turystyczna Gorczańskiego Parku Narodowego. Państwowy Instytut Geologiczny, Warszawa.

Miśkiewicz K., Golonka J., 2007. Pieniny: A proposed new cross-border Polish-Slovak Geopark. European Geoparks Network Abstracts. 7th European Geopark Network Open Conference in Scotland. Landscape and People: Earth Heritage, Culture and Economy. 13th - 16th September/ Sultaon 2007, Ulapool, Scotland, UK North West Highland Geopark, 3.

Miśkiewicz K., Golonka J., Waśkowska A., Doktor M., Słomka T., 2011. Transgraniczny geopark „Karpaty fliszowe i ich wody mineralne”. Przegląd Geologiczny, 59: 611-621.

Migoń P., 2012. Geoturystyka. Wydawnictwo Naukowe PWN, Warszawa.

Oszczypko N., Uchman A., Malata E. (eds), 2006. Rozwój paleotektoniczny basenów Karpat Zewnętrznych i pienińskiego pasa skałkowego (Palaeotectonic evolution of the Outer Carpathian and Pieniny Klippen Belt Basins). Instytut Nauk Geologicznych UJ, Kraków: 19-43.

Radwański A., 2009. The Ignacy Łukasiewicz Memortial Museum of Oil and Gas Industry in Bóbrka and historical monuments of petroleum and salt industries in the vicinity of Krosno (the Polish Outer Carpathians). Geotourism, 3 (18): 51-60.
Rajchel L., Czop M., Motyka J., Rajchel J., 2011. Skład chemiczny wód mineralnych i leczniczych rejonu Iwonicza i Rymanowa. Biuletyn Państwowego Instytutu Geologicznego, 445: 549-560.

Rychel J., Piotrowska E., Wasiluk R., 2013. Wykorzystanie technik GIS w konstrukcji map geologiczno-turystycznych parków krajobrazowych Polski północnej. In: Kunz M., Nienartowicz A. (eds), Systemy informacji geograficznej $w$ zarzadzaniu obszarami chronionymi - od teorii do praktyki. Uniwersytet Mikołaja Kopernika, Tuchola -Toruń: 32-42.

Rychel J., Kucharska M., Pochocka-Szwarc K., 2012. Mapy geologiczno-turystyczne jako jedna z form popularyzacji geoturystyki. Przeglad Geologiczny, 60: 589-592.

Słomka T., Kicińska-Świderska A., Doktor M., Joniec A., 2006. Katalog obiektów turystycznych $w$ Polsce. Kraków.

Ślączka A., Kamiński M.A., 1998. Guidebook to Excursions in the Polish Flysch Carpathians. Grzybowski Foundation, Special Publication no. 6, Kraków.

Świdziński H. 1933. „Prządki” - skałki piaskowca ciężkowickiego pod Krosnem. Zabytki Przyrody Nieożywionej Ziem Rzeczypospolitej Polskiej, 2: 94-125.

Wasiluk R., 2013. Projekt Geoparku „Dolina Wisłoka - Polski Teksas”. Przegląd Geologiczny, 61: 224-229.

Wasiluk R., Radwanek-Bąk B., Bąk B., Kopciowski R., Malata T., Szeląg A., Kochman A., Świąder A., Kłapyta P., Mocior E., Nowak A., Bieńkowska-Wasiluk M., 2013. Geologiczno-górniczo-środowiskowe warunki utworzenia geoparku „Dolina Wisłoka-Polski Teksas”. Narodowe Archiwum Geologiczne. Państwowy Instytut Geologiczny - Państwowy Instytut Badawczy Warszawa.

Wasiluk R., Radwanek-Bąk B., Bąk B., Kopciowski R., Malata T., Kochman A., Świąder A., 2014a. The Conception of the Geopark „Wisłok Valley - The Polish Texas". In: Bubniak I., Solecki A. (eds), Geo-carpathians - potential of the cognitive tourism. Wydawnictwo Ruthenus, Krosno: 47-66.

Wasiluk R., Radwanek-Bąk B., Bąk B., Kopciowski R., Malata T., Kochman A., Świąder A., 2014b. Projektowany geopark ,Dolina Wisłoka - Polski Teksas”. In: Скакун Л.З., Бубняк I.M. (eds), Геотуризм: практика i досвід. Львівський національний університет імені Івана Франка, Львів: 55-58.

Wójcik A., 1999. Zasięg lądolodu skandynawskiego na terenie Dołów Jasielsko-Sanockich (Karpaty). In: VI Konferencja stratygrafii plejstocenu Polski ,Czwartorzęd wschodniej części Kotliny Sandomierskiej”, Czudec, 31 sierpnia - 4 września 1999, 83-85.

Wójcik T., Ziaja M., Ćwik A., 2014. Potencjał geoturystyczny nieczynnych kamieniołomów Czarnorzecko-Strzyżowskiego Parku Krajobrazowego. Prace Komisji Krajobrazu Kulturowego, 26: 155-173.

Zawilińska B., Wilkońska A., Szpara K., 2015. Miejscowy potencjat turystyczny $i$ zrównoważony rozwój turystyki w opinii i działaniach lokalnych samorządów. In: Szpara K., Zawilińska B., Wilkońska A. (eds), Lokalny potencjat a zrównoważony rozwój turystyki $w$ Karpatach, Centrum UNEP/GRID-Warszawa, Rzeszów-Warszawa, 122-136. 